\title{
PERLINDUNGAN HUKUM TERHADAP PIHAK KE TIGA AKIBAT DIREKSI MELAKUKAN TINDAKAN DI LUAR ANGGARAN DASAR PERSEROAN TERBATAS
}

\author{
Putu Agung Surya Prawira, I Nyoman Putu Budiartha, Ni Made Puspa Sutariujianti \\ Fakultas Hukum, Universitas Warmadewa, Denpasar-Bali, Indonesia \\ agungsurya1707@gmail.com
}

\begin{abstract}
Abstrak
Dasar-dasar proteksi hukum terhadap pihak ketiga dalam perihal Direksi Perseroan Terbatas melaksanakan aksi di luar anggaran dasar pada pokoknya bisa dijabarkan dari pemikiran kalau prinsip di luar anggaran dasar ini telah ialah doktrin yang berlaku secara umum. Dalam hal ini, terkadang terdapat permasalahan yang terjadi maka sudah selayaknya perlindungan hukum terhadap pihak ketiga sangat diperlukan dalam menanggulangi tindakan diluar anggaran dasar perseroan terbatas. Tujuan dari penelitian ini yaitu untuk mengungkap perlindungan hukum pihak ke tiga dalam hal direksi melakukan tindakan di luar anggaran dasar perseroan terbatas serta upaya pemulihan hak-hak pihak ketiga atas tindakan diresksi di luar anggaran dasar perseroan terbatas (PT). Tipe penelitian yang diaplikasikan dalam penelitian ini yaitu penelitian normatif. Adapun sumber bahan hukum yang digunakan adalah sumber hukum primer dan sekunder. Teknik pengumpulan bahan hukum dengan studi pencatatan dokumen. Setelah bahan hukum dikumpulkan, maka selanjutnya dianalisis secara kualitatif. Hasil penelitian mengungkapkan bahwa di Indonesia bisa dikemukakan secara implisit Undangundang Perseroan Terbatas, mengakui serta menerima Doktrin di luar anggaran dasar Perseroan Terbatas. Di samping itu ada pula sebagian dasar yang bisa dipergunakan selaku alibi buat membagikan proteksi terhadap pihak ketiga. Dasar-asar tersebut meliputi asas itikad baik, asas pacta sun servanda serta doktrin di luar anggaran dasar modern. Dengan bertumpuk pada dasar-dasar tersebut, hingga dapatlah diberikan proteksi hukum preventif serta proteksi hukum represif.
\end{abstract}

Kata Kunci: Direksi, Perlindungan Hukum, Perseroan Terbatas, Pihak Ketiga

\begin{abstract}
The basics of legal protection against Third Parties in the case of the Board of Directors of a Limited Liability Company carrying out actions outside the articles of association can basically be explained from the idea that the principles outside of these articles of association are generally accepted doctrines. In this case, sometimes there are problems that occur, so legal protection for third parties is very necessary in overcoming actions outside the articles of association of the limited liability company. The purpose of this study is to reveal the legal protection of third parties in the case of directors taking actions outside the articles of association of a limited liability company in an effort to restore the rights of third parties for actions by directors outside the articles of association of a limited liability company (PT). The type of research applied in this research is normative research. The sources of legal materials used are primary and secondary legal sources. Techniques for collecting legal materials by studying document recording. After the legal material is collected, it is then analyzed qualitatively. The results of the study reveal that in Indonesia it is possible to implicitly state the Limited Liability Company Law, acknowledge and accept the Doctrine outside the articles of association of the Limited Liability Company. In addition, there are also some grounds that can be used as an alibi to provide protection against third parties. These basics include the Principle of Good Faith, the Pacta Sun Servanda Principle and the Doctrine outside the Modern constitution. By relying on these basics, preventive legal protection and repressive legal protection can be provided.
\end{abstract}

Keywords: Legal Protection, Limited Liability Company, Third Party

\section{PENDAHULUAN}

Hukum positif di Indonesia pada pokoknya memahami bentuk-bentuk industri semacam Firma (Fa), Commanditair Vennootschap (CV), Perseroan Terbatas (PT) serta Koperasi. Hendak namun dari bentuk- bentuk yang terdapat itu, tidak hanya koperasi yang memanglah didorong perkembangannya, hingga yang banyak didirikan merupakan Perseroan Terbatas (PT). Dalam kurun waktu sebagian tahun terakhir ini frekuensi pendirian PT hadapi kenaikan yang signifikan. Perihal ini bisa disimak dari pemikiran kalau dari bermacam wujud industri yang terdapat di Indonesia, semacam firma, 
persekutuan komanditer, koperasi serta lain sebagainya, hingga wujud industri PT ialah wujud yang sangat umum, apalagi kerap dikatakan kalau PT ialah wujud industri yang dominan (Nurhayati, 1995).

Ditinjau dari aspek hukum perjanjian perbuatan mendirikan, mempunyai serta mengelola Perseroan Terbatas (PT) bukanlah ialah perbuatan tunggal, melainkan semenjak wujud tubuh hukum industri diketahui telah jadi perbuatan yang mengaitkan lebih dari satu orang, apalagi banyak orang. Di dalam PT ada bermacam ikatan hukum ialah antara pemegang saham yang satu dengan yang lain, antara perseroan dengan direksi, komisaris, pegawai, serta antara perseroan dengan pihak ketiga (Soemitro, 1993). Lebih lanjut Sudaryata (2020) perseroan Terbatas menjadi bentuk perusahaan yang banyak dipilih oleh investor sebagai sarana usahanya. Hal ini tidak lepas dari keistimewaan Perseroan Terbatas yang berstatus badan hukum dengan kekayaan yang terpisah dari kekayaan pemegang sahamnya. Banyak kasus dimana pemegang saham mayoritas perseroan sekaligus sebagai direksi perseroan.

Adapun kerugian yang terjadi dalam perseroan disebabkan oleh keputusan yang telah sesuai dengan prosedur yang diatur dalam anggaran dasar PT dan peraturan yang berlaku, maka beban tersebut dibebankan kepada PT dikarenakan pihak ketiga. Namun dalam hal kerugian yang terjadi bersumber dari keputusan yang tidak sesuai dengan prosedur yang diatur dalam anggaran dasar PT serta peraturan yang berlaku atau dengan itikad buruk, maka beban tanggung jawab tersebut dilimpahkan kepada pihak yang melakukan perbuatan tersebut (Chairany et al., 2020).

Terdapat penelitian terdahulu yang relevan dengan penelitian ini yaitu Raffles (2020) direksi bertanggungjawab atas segala tindakan dan keputusan yang dibuatnya bahkan pertanggungjawaban pribadi. Namun demikian, direksi dapat terhindar dari tuntutan pertanggungjawaban secara pribadi apabila dapat membuktikan dasar dan alasannya dan didasarkan pada itikad aik dan hati-hati. Adapun menurut E.P et al., (2013) setiap anggota direksi wajib itikad baik dan penuh tanggung jawab menjalankan tugas untuk kepentingan dan usaha Perseroan. Hal ini membawa konsekuensi hukum bahwa setiap anggota direksi bertanggung jawab secara pribadi apabila yang bersangkutan bersalah atau lalai menjalankan tugasnya untuk kepentingan dan usaha Perseroan. Sedangkan hasil penelitian yang dilakukan oleh Setyarini et al., (2020) berpendapat bahwa bentuk perbuatan melawan hukum yang dilakukan oleh direksi: mempergunakan uang atau kekayaan perseroan untuk kepentingan pribadi, informasi perseroan untuk kepentingan pribadi, melakukan transaksi dengan perseroan, larangan bersaing dengan perseroan. Pertanggungjawaban direksi atas perbuatan melawan hukum diatur dalam UU No. 40 Tahun 2007 direksi bertanggung jawab atas pengurusan perseroan dimana pengurusan itu wajib dilaksanakan setiap anggota direksi dengan itikad baik dan penuh tanggung jawab. Dari hal tersebut sebaiknya Perlu optimalisasi pelaksanaan dan pengawasan UUPT yang secara substansial memberikan perlindungan kepada pelaku bisnis dan hak-hak publik lainnya.

Berdasarkan uraian diatas, maka tujuan penelitian ini yaitu mengungkap perlindungan hukum pihak ketiga dalam hal direksi melakukan tindakan di luar anggaran dasar perseroan terbatas upaya pemulihan hak-hak pihak ketiga atas tindakan diresksi di luar anggaran dasar perseroan terbatas (PT).

\section{METODE PENELITIAN}

Riset yang penulis pakai merupakan riset hukum normatif ialah dengan mengkaji peraturan perundang-undangan yang berlaku semacam: Undang-Undang Republik Indonesia No 40 Tahun 2007 tentang Perseroan Terbatas Pendekatan masalah yang akan dipergunakan pada penelitian ini ialah menggunakan pendekatan perundang-undangan yang merupakan bahwa disini penulis melihat hukum-hukum hukum yang berlaku khususnya terhadap perlindungan aturan terhadap Pihak Ketiga pada hal Direksi Perseroan Terbatas (PT) melakukan tindakan ultra vires. dan pendekatan konseptual yaitu mengutip pendapat para sarjana pada bentuk konsep serta definisi. Untuk menunjang pembahasan terhadap permasalahan yang diajukan sumber bahan hukum diperoleh dari Sumber Bahan Hukum Primer yang diperoleh berasal peraturan perundang-undangan yang berlaku mirip Undang-Undang Republik Indonesia nomor forty Tahun 2007 perihal Perseroan Terbatas. Sumber bahan hukum sekunder yaitu diperoleh dari literatur, buku-buku, jurnal, artikel dll, yang relevan dengan permasalahan yang diangkat. Adapun dalam teknik pengumpulan bahan aturan utama serta sekunder dilakukan memakai pengumpulan bahan hukum melalui studi pencatatan dokumen yang berkaitan memakai perseteruan serta bahan hukum menggunakan menginterpretasikan menggunakan menafsirkan dan menyelidiki peraturan perundang-undangan lalu dituangkan dalam karya ilmiah 
menggunakan mengkaitkan konflik yang dibahas. Sesudah bahan hukum utama serta bahan hukum sekunder terkumpul, maka bahan hukum tadi diolah serta dianalisa memakai mempergunakan metode kualitatif. sesudah melalui proses pengolahan dan analisis, kemudian bahan aturan tersebut tersaji secara naratif analisis. naratif artinya adalah pemaparan yg akan terjadi penelitian secara sistematis dan menyeluruh menyangkut warta yang bekerjasama dengan pertarungan penelitian. Sedangkan analisis adalah warta yang bekerjasama penelitian dianalisis secara cermat, sebagai akibatnya kemudian dihasilkan konklusi yang akan terjadi penelitian.

\section{HASIL DAN PEMBAHASAN}

\section{Perlindungan Hukum Pihak Ketiga dalam Hal Direksi Melakukan Tindakan di luar Anggaran Dasar Perseroan Terbatas}

Tindakan pada luar aturan dasar bisa diartikan menjadi tindakan yg melampaui berukuran yg telah ditetapkan. pada korelasi ini perlu ditegaskan bahwa yang telah diuraikan tersebut merupakan pengertian tindakan pada luar aturan dasar Perseroan Terbatas pada umumnya. menjadi istilah awam maka istilah tersebut tak hanya dikenal pada hukum Perseroan, melainkan terdapat juga dalam aneka macam bidang aturan. Bertumpu pada uraian tadi bisa dikemukakan, tindakan di luar aturan dasar ternyata dikenal baik pada hukum rapikan Negara maupun hukum Administrasi Negara. pada hukum tata Negara wewenang itu di pokoknya menyangkut hubungan antara negara menggunakan pemerintahnya yang diatur konstitusi. jika melampaui konstitusi maka pemerintah federal, provinsi atau negara bagian mampu dinyatakan sudah melakukan utindakan di luar hukum dasar. sementara itu aturan Administrasi Negara mempunyai pandangan yg lebih beragam. Bidang aturan ini mengenal tindakan di luar aturan dasar di pengertian sempit dan luas. di pengertian sempit, tindakan di luar aturan dasar terjadi bilamana pejabat tidak mempunyai kewenangan buat membuat keputusan atau membentuk keputusan dengan mekanisme yg cacat.

Pengertian tindakan diluar aturan dasar yang luas berlaku apabila terdapat penyalahgunaan kewenangan. pada hukum Perseroan baik yang berorientasi pada sistem common law juga yang menganut sistem civil law, wewenang atau kompetensi pula dikenal dan diterapkan. tetapi demikian menemukan uraian pengertian tindakan pada luar aturan dasar pada perangkat sistem civil law termasuk dalam Undang-Undang Perseroan Terbatas sangatlah sulit bahkan tidak ditentukan sama sekali. sang karena itu uraian mengenai pengertian tindakan pada luar anggaran dasar lebih banyak bertumpu pada sumber-asal yg mengacu di sistem common law. berasal perspektif hukum Perseroan pada pokoknya ada banyak sekali pengertian dan penjelasan yang diberikan bahwa tindakan di luar aturan dasar perseroan adalah sebagai berikut: tindakan pada luar aturan dasar menggambarkan tindakan-tindakan yang dilakukan oleh suatu korporasi dimana tindakan-tindakan tadi bersifat melampaui ruang lingkup kewenangan yang sudah ditetapkan dalam anggaran dasarnya.

Stephen H. Gifis mengemukakan terminologi "ultra vires" digunakan khususnya terhadap tindakan perseroan yang melebihi kekuasaannya sebagaimana diberikan oleh aturan dasarnya atau oleh peraturan yang melandasi pembentukan perseroan tersebut (Fuady, 2002). Macintyre (2007) bahwa pandangan-pandangan tersebut pada dasarnya mengandung makna, bahwa perseroan menjadi badan aturan memiliki kompetensi buat bertindak. Berhubung karena perseroan tak bisa melakukan tindakan sendiri maka diharapkan Direksi menjadi wakil perseroan yang mewujudkan tindakantindakan itu. Tindakan-tindakan yang dilakukan sang perseroan melalui Direksinya haruslah memperoleh persetujuan atau termasuk pada ruang lingkup tindakan-tindakan yang diatur pada ketentuan-ketentuan tentang tujuan perseroan (company's objects clause). apabila tak sesuai atau tak tercantum pada ketentuan-ketentuan tersebut, maka terjadilah tindakan yg melampaui kompetensi. Bilamana suatu kewenangan yang telah ditetapkan dalam suatu kewenangan umum terlampaui, maka tindakan-tindakan yang telah dilakukan dengan melampaui kewenangan itu merupakan tindakantindakan yang cacat seperti halnya ultra vires. The ultra vires doctrine menyediakan sarana kontrol terhadap pihak-pihak yang tindakannya melampaui kewenangan.

Tentang impak yang bisa ditimbulkan sang Doktrin tindakan pada luar anggarana dasar Perseroan Terbatas terhadap perjanjian-perjanjian yang dibuat sang perseroan intinya sudah disinggung pada uraian tentang pengertian tindakan Direksi pada luar aturan dasar Perseroan itu sendiri, dimana dikemukakan bahwa perjanjian yg demikian adalah tidak legal (illegal). Asal uraian tersebut sebenarnya sudah tampak menggunakan jelas, dimana Doktrin tindakan pada luar anggaran dasar memang mempunyai impak terhadap perjanjian-perjanjian yg didesain perseroan dengan 
pihak ketiga. Beberapa kepustakaan pada pokoknya mengemukakan, perjanjian pada luar aturan dasar yang dinyatakan tidak legal itu merupakan null and void (batal demi hukum) serta voidable (dapat dimohonkan pembatalan). tetapi yg menjadi persoalan, bagaimana uraiannya sebagai akibatnya perjanjian tersebut dapat dinyatakan demikian atau kebalikannya. Dalam konsep Subjective objects clause pada pokoknya diuraikan sebagai suatu ketentuan pada anggaran dasar perseroan yg dapat diinterpretasikan secara fleksibel, terlebih-lebih jika akibat penafsiran tadi menyampaikan laba kepada perseroan, maka aktivitas-kegiatan lain kendatipun tidak tercantum pada maksud dan tujuan serta aktivitas usaha bisa ditinjau menjadi kompetensi perseroan buat melaksanakannya. Subjective objects clause tadi terdapat pada clause tiga(c). berdasarkan adanya klausul itu maka The Court of Appeal kemudian memutuskan bahwa tindakan-tindakan melaksanakan kegiatan-aktivitas di luar ruang lingkup business AS general, civil and engineering contractors and in particular to construct houses itu bukanlah tindakan pada luar aturan dasar Perseroan Terbatas. Tindakan-tindakan yang berdasarkan di clause 3(c) artinya tindakan pada dalam anggaran dasar Perseroan Terbatas (intra vires).

Sesuai uraian tersebut dapat dikemukakan, tindakan pada dalam anggaran dasar (intra vires) sebenarnya artinya kebalikan dari tindakan di luar anggaran dasar Perseroan Terbatas (ultra vires), dan asal putusan The Court of Appeal bisa disaksikan tentang pengakuan terhadap kekuatan mengikat berasal suatu memorandum of association (aturan dasar) perseroan. Dalam contoh masalah PT Dhaeseng/PT Interland Kontra PT usaha pakaian terdapat kabar dimana di pokoknya Presiden Direktur menghasilkan Surat Pernyataan Hutang kepada PT usaha sandang buat dan atas nama PT Dhaeseng/PT Interland (badan aturan) tanpa persetujuan Komisaris, sesuai dengan ketentuan pada dalam anggaran dasar (Chairany et al., 2020).

Tindakan yang dilakukan oleh Presiden Direktur atau Direksi tadi sebenarnya telah memenuhi unsur-unsur adanya tindakan melampaui kompetensi Direksi yang melakukan tindakan di luar aturan dasar Perseroan Terbatas, sebab dalam praktek telah merupakan suatu kelaziman menuangkan ke pada anggaran dasar ketentuan mengenai kewajiban Direksi buat memperoleh persetujuan Komisaris apabila hendak mengikatkan perseroan pada perjanjian hutang-piutang. Ternyata Direksi tidak menempuh mekanisme tadi sebagai akibatnya tindakannya itu bisa dikualifikasi sebagai tindakan di luar anggaran dasar Perseroan Terbatas

Pengadilan Negeri yang menangani masalah tersebut pada intinya menetapkan memang benar bahwa hutang tadi adalah tanggung jawab langsung Presiden Direktur PT Dhasaeng, menggunakan hanya mengungkapkan, oleh karena tindakan membuat Surat Pernyataan Hutang itu tanpa persetujuan komisaris, maka hutang tadi menjadi tanggung jawab pribadi Presiden Direktur tadi. Putusan itu sama sekali tidak menyebut doktrin tindakan diluar anggaran dasar. Terlepas asal penerimaan secara substansial, hal ini bisa ditimbulkan karena kata tindakan pada luar anggaran dasar belum begitu terkenal di Indonesia.

Pada tingkat banding, Pengadilan Tinggi bahkan membatalkan Putusan Pengadilan Negeri dengan alasan sebagai berikut:

a. Surat perjanjian pengakuan pembayaran hutang bahan tekstil tidak bisa digolongkan mengikat perseroan menjadi penjamin (Pasal 11 ayat (2) aturan Dasar PT Dhasaeng);

b. Surat perjanjian di atas, merupakan pembelian bahan tekstil, yang termasuk pada "bidang usaha" perseroan, sehingga tergugat (Presiden Direktur) dianggap tetap berwenang serta sah melakukan perbuatan tersebut (tanpa persetujuan komisaris).

Baru pada taraf kasasi (Mahkamah Agung), diterapkan doktrin tindak pada luar aturan dasar. berbagai masalah tersebut pada atas intinya telah memperlihatkan akibat atau dampak tindakan di luar anggaran dasar perseroan terbatas terhadap perjanjian antara perseroan menggunakan pihak ketiga. terdapat pun akibat yang dimaksudkan artinya menjadi berikut:

a. Oleh sebab tindakan di luar aturan dasar perseroan terbatas ialah tindakan melampaui kompetensi dan bersifat tidak sah sebagai akibatnya batal demi aturan, maka perjanjian-perjanjian yg ialah akibat perwujudan nyata asal tindakan di luar anggaran dasar perseroan terbatas juga bersifat tidak sah.

b. Oleh karena perjanjian-perjanjian yang pada awalnya dimaksudkan menjadi ikatan antara perseroan serta pihak ketiga dinyatakan tidak sah, dimana hal ini menimbulkan dampak berupa beralihnya tanggung jawab Direksi secara eksklusif. 
Berasal setiap akibat tindakan di luar aturan dasar Perseroan Terbatas tadi intinya bisa mengakibatkan kerugian pada pihak ketiga, baik yang menyangkut pelaksanaan perjanjiannya sendiri juga kelangsungan eksistensi. sang karena itu sangat berdasar apabila pihak ketiga membutuhkan proteksi hukum.

\section{Upaya Pemulihan Hak-Hak Pihak Ketiga Atas Tindakan Diresksi di Luar Anggaran Dasar Perseroan Terbatas (PT)}

Upaya pemulihan atau remedy mencerminkan dua tindakan, pertama, tindakan yg mengandung aspek memperbaiki dan mencegah, serta yang kedua, tindakan atau upaya yang mengandung aspek yg bertujuan memulihkan. dengan demikian dapat dikemukakan bentuk-bentuk upaya remedial terhadap kerugian akibat tindakan pada luar anggaran dasar tadi meliputi tindakan ratifikasi serta pemberian ganti rugi. ratifikasi berarti ratifikasi terhadap perjanjian tindakan di luar aturan dasar sehingga sebagai tanggung jawab perseroan, maka menggunakan demikian Direksi terbebaskan berasal tanggung jawab yang bertujuan memperbaiki kondisi perjanjian serta mencegah kerugian (Fuady, 2002). Ganti rugi atau damages pada dasarnya merupakan suatu kompensasi dalam bentuk pemberian sejumlah uang. Di samping itu pemberian ganti rugi juga merupakan salah satu bentuk upaya remedial yang bersifat menanggulangi kerugian yang timbul. Dalam hal pihak ketiga yang dirugikan merupakan kreditur, maka mereka dapat melakukan injunction atau mencegah perseroan membelanjakan pinjaman dari pihak ketiga, dan tracing atau menarik kembali pinjaman sepanjang dapat ditemukan dalam kondisi utuh. Dalam hal Direksi yang dibebani tanggung jawab pribadi tidak mampu bertanggungjawab misalnya karena alasan tidak memiliki kekayaan yang cukup, maka langkah yang dapat dipandang sebagai solusinya adalah melakukan proses substitution.

Dengan langkah ini, perseroan terlebih dahulu melakukan penalangan terhadap kerugian pihak ketiga dan selanjutnya Direksi berkewajiban mempertanggungjawabkannya kepada perseroan. Dalam hubungan ini yang diutamakan adalah memulihkan hak-hak pihak ketiga.

\section{SIMPULAN DAN SARAN}

\section{Simpulan}

Dasar perlindungan hukum terhadap Pihak Ketiga dalam hal Direksi melakukan tindakan diluar anggaran dasar perseroan terbatas, pada pokoknya dapat diuraikan dari pandangan bahwa prinsip tindakan di luar anggaran dasar merupakan doktrin yang berlaku secara universal. Di Indonesia dapat dikemukakan secara implisit Undang-undang Nomor 40 Tahun 2007 tentang Perseroan Terbatas mengakui dan menerima Doktrin tindakan di luar anggaran dasar. Pengakuan dan penerimaan ini tercermin dari adanya ketentuan- ketentuan yang berkaitan dengan maksud dan tujuan serta kegiatan usaha perseroan. Di samping itu terdapat pula beberapa dasar yang dapat dipergunakan sebagai alasan untuk memberikan perlindungan terhadap pihak ketiga. Dasar-dasar tersebut meliputi Asas Itikad Baik, Asas Pacta Sun Servanda dan Doktrin tindakan di luar anggaran dasar Modern. Dengan bertumpu pada dasar-dasar tersebut, maka dapatlah diberikan perlindungan hukum preventif dan perlindungan hukum represif. Adapun upaya pemulihan terhadap pihak ketiga atas tindakan Direksi pada luar aturan dasar Perseroan Terbatas mencerminkan dua tindakan, pertama, tindakan yang mengandung aspek memperbaiki serta mencegah, serta yang ke 2, tindakan atau upaya yg mengandung aspek yg bertujuan memulihkan. menggunakan demikian bisa dikemukakan bentukbentuk upaya remedial terhadap kerugian dampak tindakan diluar anggaran dasar tadi meliputi tindakan pengesahan dan anugerah ganti rugi. pengesahan berarti ratifikasi terhadap perjanjian yg diluar anggaran dasar sehingga menjadi tanggung jawab perseroan, maka menggunakan demikian Direksi terbebaskan berasal tanggung jawab yang bertujuan memperbaiki kondisi perjanjian serta mencegah kerugian. Ganti rugi atau damages intinya adalah suatu kompensasi pada bentuk pemberian sejumlah uang. di samping itu pemberian ganti rugi pula artinya galat satu bentuk upaya remedial yang bersifat menanggulangi kerugian yg muncul. dalam hal pihak ketiga yang dirugikan ialah kreditur, maka mereka bisa melakukan injunction atau mencegah perseroan membelanjakan pinjaman berasal pihak ketiga, dan tracing atau menarik balik pinjaman sepanjang dapat ditemukan dalam syarat utuh. dalam hal Direksi yg dibebani tanggung jawab pribadi tidak bisa bertanggungjawab misalnya sebab alasan tidak memiliki kekayaan yang cukup, maka langkah yg dapat dicermati menjadi solusinya artinya melakukan proses substitution dengan langkah ini, perseroan terlebih dahulu melakukan penalangan terhadap kerugian pihak ketiga serta selanjutnya Direksi berkewajiban 
mempertanggungjawabkannya pada perseroan. pada korelasi ini yg diutamakan adalah memulihkan hak-hak pihak ketiga.

\section{Saran}

Prioritas utama pada penerapan Doktrin tindakan pada luar anggaran dasar perseroan terbatas pada dasarnya ialah pencegahan terhadap tindakan Direksi yang melampaui kewenangan perseroan. Berkaitan menggunakan upaya mendukung pencegahan tersebut maka baik Direksi maupun pihak ketiga yg akan menjalin korelasi kontraktual menggunakan perseroan hendaknya tahu terlebih dahulu ketentuan-ketentuan tentang maksud serta tujuan aktivitas perjuangan perseroan yg bersangkutan. Pemahaman itu diantaranya dapat diperoleh melalui konsultasi aturan. Dalam upaya menciptakan kepastian aturan, maka aspek-aspek yang berkaitan dengan dasar-dasar proteksi aturan serta upaya pemulihan hak-hak pihak ketiga atas tindakan diluar aturan dasar perseroan terbatas, Diresksi perseroan perlu diatur secara tegas serta terang pada Undang-undang wacana Perseroan Terbatas Penegasan serta rincian tentang aspek-aspek tersebut bisa jua dituangkan pada anggaran dasar perseroan yg pada dasarnya adalah konstitusi bagi perseroan yang bersangkutan.

\section{DAFTAR PUSTAKA}

Chairany, M. P., Indrawati, Y., \& Sadjarwo, I. W. (2020). Tanggung Jawab Perseroan Terbatas Atas Terjadinya Hibah Saham yang dilakukan Berdasarkan Surat Kuasa yang Telah Berakhir (Studi Kasus Putusan Pengadilan Negeri Nomor 94/Pdt.G/2017/Pn.Lbp). Notary Indonesian, 2(4), 351-368.

E.P, M. V., Siregar, R., \& Windha. (2013). Pertanggungjawaban Direksi karena Kelalaian Atau Kesalahannya yang Mengakibatkan Perseroan Pailit. Jurnal Hukum Ekonomi, 1(1), 1-9.

Fuady, M. (2002). Doktrin-Doktrin Modern dalam Corporate Law dan Eksistensinya Dalam Hukum Indonesia. PT. Citra Aditya Bakti, Bandung.

Macintyre, E. (2007). Essensial Of Business law Person Education Limited. Harlow, England.

Nurhayati, I. (1995). Ulasan Tentang Status Badan Hukum Perseroan Terbatas Menurut UndangUndang Nomor 1 Tahun 1995 tentang Perseroan Terbatas.

Raffles. (2020). Tanggung Jawab dan Perlindungan Hukum Direksi dalam Pengurusan Perseroan Terbatas. Undang: Jurnal Hukum, 3(1), 108-137.

Setyarini, D. M., Mahendrawati, N. L. M., \& Arini, D. G. D. (2020). Pertanggungjawaban Direksi Perseroan Terbatas Yang Melakukan Perbuatan Melawan Hukum. Jurnal Analogi Hukum, 2(1), $12-16$.

Soemitro, R. (1993). Hukum Perseroan Terbatas. Yayasan dan Wakaf, PT. Eresco, Bandung.

Sudaryata. (2020). Tanggung Jawab Pemegang Saham Mayoritas yang Merangkap Sebagai Direksi Terhadap Kerugian Pihak Ketiga Akibat Perbuatan Melawan Hukum Perseroan. Jurnal Bina Mulia Hukum, 4(2), 313-325. 